\title{
Analysing Powe Flow Solution with Optimal Unified Power.Flow Controller
}

\author{
D. Srilatha ${ }^{\# 1}$, S. Sivanagaraju ${ }^{2}$ \\ ${ }^{\# 1}$ Associate Professor in EEE, Prakasam Engineering College, Kandukur, A.P. \\ ${ }^{2}$ Professor in EEE, University College of Engineering, JNTU Kakinada, A.P. \\ srilatha.dande@gmail.com \\ venkatasuresh4@gmail.com
}

\begin{abstract}
The electric power system function is to maintain the power plants under pool operation and utility centers to supply the active and reactive powers demanded by the loads connected to the system. Now a day's transmission systems are difficult to operate as well as more stressed due to unscheduled power flows and more losses of growing demand. However many HV systems are operating below thermal rating due to the voltage and stability limit. Later on rapid development in the technology introduces high rating and fast acting switching devices with power electronic components. Flexible AC transmission system (FACTs) controllers equipped with fast acting semi conductor devices designed to control one or more power system parameters for the effective operation of system. In this paper, a novel FACTs controller namely, optimal unified power flow controller (OUPFC) is proposed with its current injection model along with its incorporation procedure. The effect of this device on system parameters is analyzed on standard test systems with its graphical and numerical results.
\end{abstract}

Keyword- Optimal unified power flow controller; Current based model; PST; UPFC

\section{INTRODUCTION}

The technological developments in power electronics industry increases the opportunities to develop new kind of flexible AC transmission system controllers popularly known as FACTs controllers. In general, the conventional FACTs controllers can control either the bus voltage magnitude, voltage angle at buses or active and reactive power flow in transmission lines. Due to this, the existing controllers can be called as single function controllers. In real, to solve the practical problems, the realistic controllers must control the multiple system parameters simultaneously rather than single system parameter.

This led to the development of FACTS devices over which OUPFC is the effective device developed to improve the power system reliability by controlling the power flow through lines. OUPFC consists of the combination of UPFC and PST which exhibit their individual better features in controlling power flows in transmission lines. UPFC able to control real, reactive power flows and voltage magnitude at the buses and PST controls phase angle of the bus voltages [1-2].

Previously power injection and voltage based models have been developed to model the FACTS devices. Anew approach to model OUPFC is developed known as current based model. This model shows the better convergence and reliability of the existed system [3]. Recent literature reveals PIM of OUPFC for optimal power system performance. This model was tested with OPF algorithm to optimize the fuel cost and loss [4]. A. Lashkar Ara et al., developed contingency analysis based OUPFC to minimize average loadability on transmission system and to enhance system security under single contingency condition [5].

After careful review of the literature, it is noticed that, using optimal unified power flow controller (OUPFC) multiple system parameters can be controlled. The existing literature presents the power injection model of this device. But there is a scope to model this device using current based model also. Using this motivation, in this paper, current based model of OUPFC is presented along with its necessary mathematical derivation and load flow incorporation procedure. To show the effectiveness of the proposed current based model over the existing power injection model, the analytical results with respective numerical results are presented. And also, the effectiveness of OUPFC over the conventional phase shifting transformer (PST) and unified power flow controller (UPFC) is presented with necessary graphical and numerical results.

\section{WORKING PRINCIPLE OF OUPFC}

Optimal Unified Power Flow Controller (OUPFC) $[6,7]$ consists of two triple winding transformers such as injecting and exciting transformers connected in series and shunt with the line as shown in Fig.1. It is the combination of PST and UPFC having two voltage source converters. PST is connected between secondary windings of two transformers through mechanical switches to shift the transmission angle based on the system condition. Series and shunt converters of UPFC are connected to the territory windings of injecting and exciting transformers in a way to inject current in to the line. The series converter injects a voltage with controllable magnitude and phase angle in series with the line via an injecting transformer. Shunt converter either supply or consumes the real power demanded by the series converter to balance the real power between converters. It also 
supply or absorb reactive power to provide desired reactive shunt compensation for the line moreover controls the bus voltage.

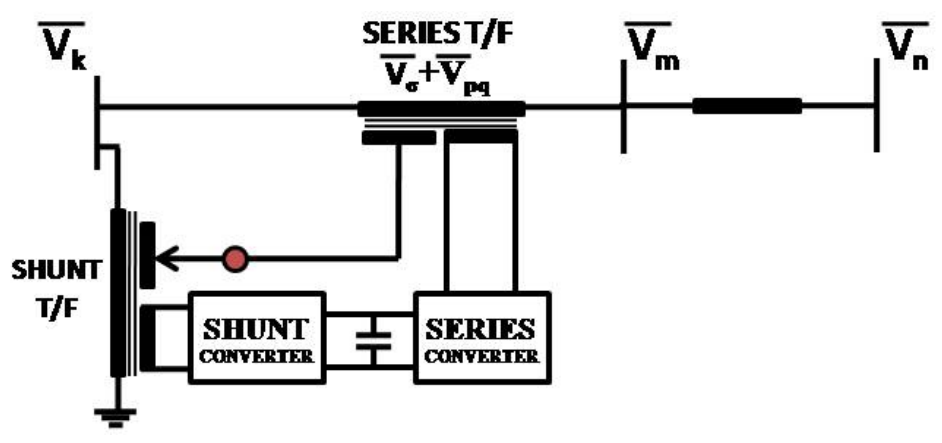

Fig.1 Basic schematic diagram of OUPFC

\section{A. Mathematical Model of Phase Shifting Transformer}

The Phase Shifting Transformer (PST) is used to advance the phase angle of the bus voltage. It is represented by an ideal transformer as in previous cases but with a turn's ratio which is a complex number. Let the turns ratio be $\left(a_{s}+j b_{s}\right)$. The configuration of phase shifting transformer is shown in Fig.2.

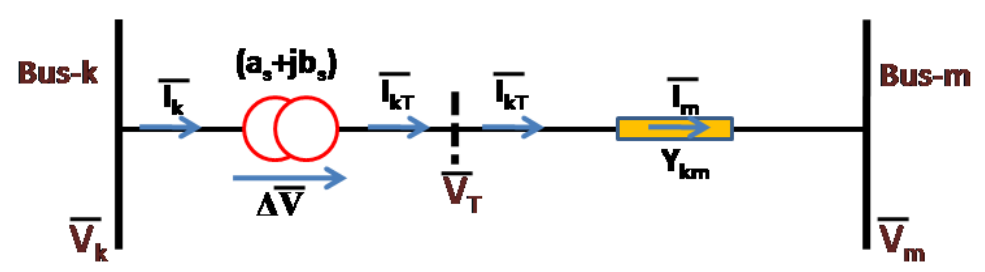

Fig.2 Basic configuration of PST

By following the mathematical model given in [48] to get affect of PST on system performance. The elements of admittance matrix between the buses where PST is connected are modified as

$$
\mathrm{Y}_{\mathrm{kk}}=\frac{\mathrm{Y}_{\mathrm{km}}}{\left(\mathrm{a}^{2}+\mathrm{b}^{2}\right)} ; \mathrm{Y}_{\mathrm{km}}=-\frac{\mathrm{Y}_{\mathrm{km}}}{\left(\mathrm{a}_{\mathrm{s}}-\mathrm{jb} \mathrm{b}_{\mathrm{s}}\right)} ; \mathrm{Y}_{\mathrm{mk}}=-\frac{\mathrm{Y}_{\mathrm{mk}}}{\left(\mathrm{a}_{\mathrm{s}}+\mathrm{jb} \mathrm{b}_{\mathrm{s}}\right)} ; \mathrm{Y}_{\mathrm{mm}}=\mathrm{Y}_{\mathrm{mk}}
$$

\section{B. Mathematical Model of UPFC}

The general structure of UPFC contains "back-to-back" AC to DC voltage source converters through a common DC link capacitor shown in Fig.3. First converter (CONVERTER-I) is connected in shunt and the second one (CONVERTER-II) in series with the line. The shunt converter is primarily used to provide active power demand of the series converter through a common DC link. Converter-I can also generate or absorb reactive power, if it is desired, and thereby provide independent shunt reactive compensation for the line. Converter-II provides the main function of the UPFC by injecting a voltage with controllable magnitude and phase angle in series with the line.

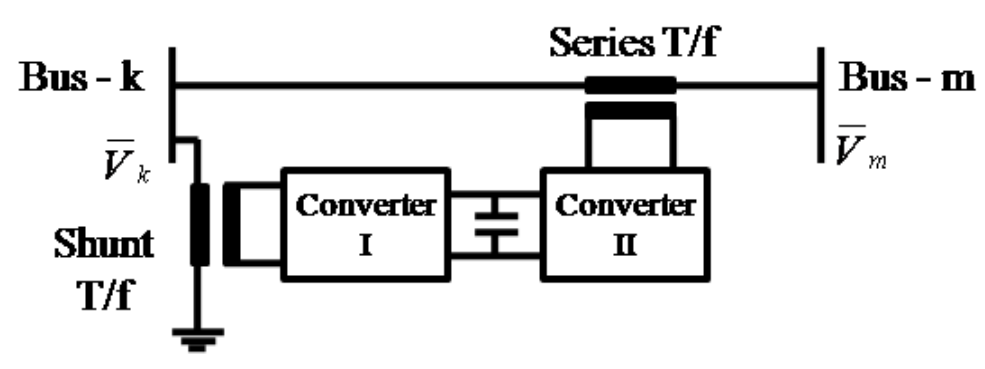

Fig.3 Basic schematic diagram of UPFC

The final power injection model of UPFC is shown in Fig.4

$$
\mathrm{P}_{\mathrm{k}}^{\mathrm{UPFC}}=0.02 \mathrm{rV}_{\mathrm{k}}^{2} \mathrm{~B}_{\mathrm{se}} \operatorname{sim} \gamma-1.02 \mathrm{rV}_{\mathrm{k}} \mathrm{V}_{\mathrm{m}} \mathrm{B}_{\mathrm{se}} \sin \left(\delta_{\mathrm{se}}+\gamma\right)
$$




$$
\begin{aligned}
& \mathrm{Q}_{\mathrm{k}}^{\mathrm{UPC}}=-\mathrm{rV}_{\mathrm{k}}^{2} \mathrm{~B}_{\mathrm{se}} \cos \gamma+\mathrm{Q}_{\mathrm{sh}}^{\mathrm{UPFC}} \\
& \mathrm{P}_{\mathrm{m}}^{\mathrm{UPFC}}=\mathrm{rV}_{\mathrm{k}} \mathrm{V}_{\mathrm{m}} \mathrm{B}_{\mathrm{se}} \sin \left(\delta_{\mathrm{se}}+\gamma\right) \\
& \mathrm{Q}_{\mathrm{m}}^{\mathrm{UPFC}}=\mathrm{rV}_{\mathrm{k}} \mathrm{V}_{\mathrm{m}} \mathrm{B}_{\mathrm{se}} \cos \left(\delta_{\mathrm{se}}+\gamma\right)
\end{aligned}
$$

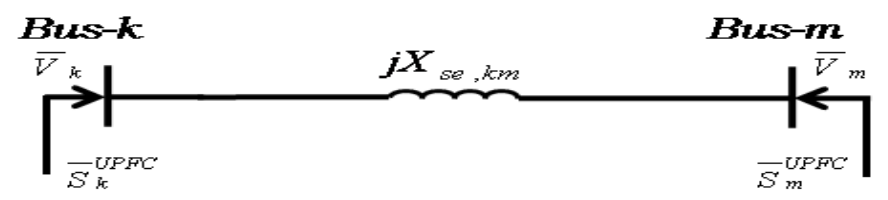

Fig.4 Power injection model of UPFC

\section{Power Injection Model of OUPFC}

The complete power injection model for OUPFC is taken from [8]. The power injections at the OUPFC connected buses can be expressed as

$$
\begin{aligned}
\mathrm{P}_{\mathrm{k}}= & -\mathrm{b}_{\mathrm{s}} \mathrm{t} \cdot \mathrm{V}_{\mathrm{k}} \cdot \mathrm{V}_{\mathrm{m}} \operatorname{Sin}(\varphi+\sigma)-\mathrm{b}_{\mathrm{s}} \mathrm{r} \cdot \mathrm{V}_{\mathrm{k}} \cdot \mathrm{V}_{\mathrm{m}} \operatorname{Sin}(\varphi+\rho) \\
\mathrm{Q}_{\mathrm{k}}= & -\mathrm{b}_{\mathrm{s}} \cdot \mathrm{V}_{\mathrm{k}} \cdot{ }^{2}\left(\mathrm{t}^{2}+\mathrm{r}^{2}\right)-2 \cdot \mathrm{b}_{\mathrm{s}} \mathrm{t} \cdot \mathrm{r} \cdot \mathrm{V}_{\mathrm{k}} \cdot{ }^{2} \operatorname{Cos}(\sigma-\rho)-2 \cdot \mathrm{b}_{\mathrm{s}} \mathrm{t} . . \mathrm{V}_{\mathrm{k}} \cdot{ }^{2} \operatorname{Cos}(\sigma) \\
& -2 \cdot \mathrm{b}_{\mathrm{s}} \mathrm{t} . . \mathrm{V}_{\mathrm{k}} \cdot{ }^{2} \operatorname{Cos}(\rho)+\mathrm{b}_{\mathrm{s}} \mathrm{r} \mathrm{t} \cdot \mathrm{V}_{\mathrm{k}} \cdot \mathrm{V}_{\mathrm{m}} \operatorname{Cos}(\varphi+\sigma)+\mathrm{b}_{\mathrm{s}} \mathrm{r} \mathrm{t} \cdot \mathrm{V}_{\mathrm{k}} \cdot \mathrm{V}_{\mathrm{m}} \operatorname{Cos}(\varphi+\rho)
\end{aligned}
$$

Similarly, at mth bus can be expressed as

$$
\begin{gathered}
P_{m}=-P_{k} \\
Q_{m}=b_{s} t \cdot V_{k} \cdot V_{m} \operatorname{Cos}(\varphi+\sigma)+b_{s} r \cdot V_{k} \cdot V_{m} \operatorname{Sin}(\varphi+\rho)
\end{gathered}
$$

\section{III.CURRENT BASED MODEL OF OUPFC}

In current based (CB) model of OUPFC, the injected current in to the transmission line is given by,

$$
\overline{\mathrm{I}}=\left(\mathrm{V}_{\mathrm{k}} \angle \delta_{\mathrm{k}}+\mathrm{r} . \mathrm{V}_{\mathrm{k}} \angle\left(\delta_{\mathrm{k}}+\gamma\right)+\mathrm{t} . \mathrm{V}_{\mathrm{k}} \angle\left(\delta_{\mathrm{k}}+\sigma\right)-\mathrm{V}_{\mathrm{m}} \angle \delta_{\mathrm{m}}\right) \times \mathrm{jb} \text { se }
$$

OUPFC device injecting power at $k$ th bus is,

$$
\begin{gathered}
\mathrm{S}_{\mathrm{k}}^{\mathrm{d}}=\overline{\mathrm{V}_{\mathrm{k}}} \times \overline{\mathrm{I}} * \\
\mathrm{~S}_{\mathrm{k}}^{\mathrm{d}}=\left(\mathrm{V}_{\mathrm{k}} \angle \delta_{\mathrm{k}}\right) \times\left(\left(\left(\left(\mathrm{V}_{\mathrm{k}} \angle \delta_{\mathrm{k}}+\mathrm{r} \cdot \mathrm{V}_{\mathrm{k}} \angle\left(\delta_{\mathrm{k}}+\gamma\right)+\mathrm{t} \cdot \mathrm{V}_{\mathrm{k}} \angle\left(\delta_{\mathrm{k}}+\sigma\right)-\mathrm{V}_{\mathrm{m}} \angle \delta_{\mathrm{m}}\right)\right) \times \mathrm{jb} \mathrm{se}\right)^{*}\right.
\end{gathered}
$$

On simplifying the above expression series device injecting real and reactive powers are obtained as,

$$
\begin{gathered}
\mathrm{P}_{\mathrm{k}}^{\mathrm{d}}=-\mathrm{V}_{\mathrm{k}} \mathrm{V}_{\mathrm{m}} \mathrm{b}_{\mathrm{se}} \cdot \sin \left(\delta_{\mathrm{k}}-\delta_{\mathrm{m}}\right)-\mathrm{rV}_{\mathrm{k}}{ }^{2} \mathrm{~b}_{\mathrm{se}} \operatorname{sim} \gamma-\mathrm{tV}_{\mathrm{k}}{ }^{2} \mathrm{~b}_{\mathrm{se}} \operatorname{sain} \sigma \\
\mathrm{Q}_{\mathrm{k}}^{\mathrm{d}}=-\mathrm{V}_{\mathrm{k}}^{2} \mathrm{~b}_{\mathrm{se}}+\mathrm{rV}_{\mathrm{k}}{ }^{2}+\mathrm{V}_{\mathrm{k}} \mathrm{V}_{\mathrm{m}} \cdot \mathrm{b}_{\mathrm{se}} \cos \left(\delta_{\mathrm{k}}-\delta_{\mathrm{m}}\right)-\mathrm{rV}_{\mathrm{k}}{ }^{2} \mathrm{~b}_{\mathrm{se}} \cos \gamma-\mathrm{tV}_{\mathrm{k}}{ }^{2} \mathrm{~b}_{\mathrm{se}} \cos \sigma
\end{gathered}
$$

Similarly real and reactive powers injected by series converter at mth bus are calculated as,

$$
\begin{gathered}
\mathrm{S}_{\mathrm{m}}^{\mathrm{d}}=\overline{\mathrm{V}_{\mathrm{m}}} \times \overline{\mathrm{I}} * \\
\mathrm{~S}_{\mathrm{m}}^{\mathrm{d}}=\left(\mathrm{V}_{\mathrm{m}} \angle \delta_{\mathrm{m}}\right) \times\left(\left(\left(\left(\mathrm{V}_{\mathrm{k}} \angle \delta_{\mathrm{k}}+\mathrm{r} \cdot \mathrm{V}_{\mathrm{k}} \angle\left(\delta_{\mathrm{k}}+\gamma\right)+\mathrm{t} \cdot \mathrm{V}_{\mathrm{k}} \angle\left(\delta_{\mathrm{k}}+\sigma\right)-\mathrm{V}_{\mathrm{m}} \angle \delta_{\mathrm{m}}\right)\right) \times \mathrm{jb} \mathrm{se}\right) *\right.
\end{gathered}
$$

On simplifying the above expression ,

$$
\begin{aligned}
& \mathrm{P}_{\mathrm{m}}^{\mathrm{d}}=-\mathrm{V}_{\mathrm{k}} \mathrm{V}_{\mathrm{m}} \mathrm{b}_{\mathrm{se}} \sin \left(\delta_{\mathrm{k}}-\delta_{\mathrm{m}}\right)-\mathrm{rV}_{\mathrm{k}} \mathrm{V}_{\mathrm{m} .} \mathrm{b}_{\mathrm{se}} \sin \left(\delta_{\mathrm{k}}-\delta_{\mathrm{m}}+\gamma\right) \\
& -\mathrm{tV}_{\mathrm{k}} \mathrm{V}_{\mathrm{m}} \mathrm{b}_{\mathrm{se}} \sin \left(\delta_{\mathrm{k}}-\delta_{\mathrm{m}}+\sigma\right) \\
& \mathrm{Q}_{\mathrm{m}}^{\mathrm{d}}=\mathrm{V}_{\mathrm{m}}^{2} \mathrm{~b}_{\mathrm{se}}-\mathrm{V}_{\mathrm{k}} \mathrm{V}_{\mathrm{m}} \mathrm{b}_{\mathrm{se}} \cos \left(\delta_{\mathrm{k}}-\delta_{\mathrm{m}}\right)-\mathrm{rV}_{\mathrm{k}} \mathrm{V}_{\mathrm{m} .} \mathrm{b}_{\mathrm{se}} \cos \left(\delta_{\mathrm{k}}-\delta_{\mathrm{m}}+\gamma\right) \\
& +\mathrm{tV}_{\mathrm{k}} \mathrm{V}_{\mathrm{m}} \mathrm{b}_{\mathrm{se}} \cos \left(\delta_{\mathrm{k}}-\delta_{\mathrm{m}}+\sigma\right)
\end{aligned}
$$

Shunt converter injecting power at kth bus is calculated as,

$$
\begin{gathered}
\mathrm{S}_{\mathrm{se}}=\overline{\mathrm{V}_{\mathrm{inj}}} \times \overline{\mathrm{I}} * \\
\mathrm{~S}_{\mathrm{se}}=\begin{array}{c}
\left(\mathrm{r} . \mathrm{V}_{\mathrm{k}} \angle\left(\delta_{\mathrm{k}}+\gamma\right)+\mathrm{t} \cdot \mathrm{V}_{\mathrm{k}} \angle\left(\delta_{\mathrm{k}}+\sigma\right)\right) \times \\
\left(\left(\left(\left(\mathrm{V}_{\mathrm{k}} \angle \delta_{\mathrm{k}}+\mathrm{r} \cdot \mathrm{V}_{\mathrm{k}} \angle\left(\delta_{\mathrm{k}}+\gamma\right)+\mathrm{t} \mathrm{V}_{\mathrm{k}} \angle\left(\delta_{\mathrm{k}}+\sigma\right)-\mathrm{V}_{\mathrm{m}} \angle \delta_{\mathrm{m}}\right)\right) \times \mathrm{jb} \mathrm{se}_{\mathrm{se}}\right) *\right.
\end{array}
\end{gathered}
$$

Real power injected at kth bus is 


$$
\begin{aligned}
\mathrm{P}_{\mathrm{se}}=\mathrm{r}^{2} \mathrm{~V}_{\mathrm{k}}^{2} \mathrm{~b}_{\mathrm{se}} \sin \gamma-\mathrm{rV}_{\mathrm{k}} \mathrm{V}_{\mathrm{m} .} \mathrm{b}_{\mathrm{se}} \sin \left(\delta_{\mathrm{k}}-\delta_{\mathrm{m}}+\gamma\right) \\
-\mathrm{tV}_{\mathrm{k}} \mathrm{V}_{\mathrm{m}} \mathrm{b}_{\mathrm{se}} \sin \left(\delta_{\mathrm{k}}-\delta_{\mathrm{m}}+\sigma\right)-\mathrm{tV}_{\mathrm{k}}^{2} \mathrm{~b}_{\mathrm{se}} \sin \sigma
\end{aligned}
$$

Net active and reactive powers injected by the device at $k$ th and $m$ th bus are,

$$
\begin{gathered}
\mathrm{P}_{\mathrm{k}}^{\text {OUPFC }}=\mathrm{P}_{\mathrm{k}}^{\mathrm{d}}+\mathrm{P}_{\mathrm{se}} \\
\mathrm{Q}_{\mathrm{k}}^{\text {OUPFC }}=\mathrm{Q}_{\mathrm{k}}^{\mathrm{d}} \\
\mathrm{P}_{\mathrm{m}}^{\text {OUPFC }}=\mathrm{P}_{\mathrm{m}}^{\mathrm{d}} \\
\mathrm{Q}_{\mathrm{m}}^{\text {OUPFC }}=\mathrm{Q}_{\mathrm{m}}^{\mathrm{d}}
\end{gathered}
$$

The detailed equations are derived as follows,

$$
\begin{aligned}
& \mathrm{P}_{\mathrm{k}}^{\mathrm{OUPFC}}=\left(-\mathrm{V}_{\mathrm{k}} \mathrm{V}_{\mathrm{m}} \mathrm{b}_{\mathrm{se}} \sin \left(\delta_{\mathrm{k}}-\delta_{\mathrm{m}}\right)-\mathrm{rV}_{\mathrm{k}} \mathrm{V}_{\mathrm{m} .} \mathrm{b}_{\mathrm{se}}\left(\sin \left(\delta_{\mathrm{k}}-\delta_{\mathrm{m}}+\gamma\right)\right) .\right. \\
& -\mathrm{tV}_{\mathrm{k}} \mathrm{V}_{\mathrm{m}} \mathrm{b}_{\mathrm{se}}\left(\sin \left(\delta_{\mathrm{k}}-\delta_{\mathrm{m}}+\sigma\right)\right) \\
& \mathrm{Q}_{\mathrm{k}}^{\text {OUPFC }}=-\mathrm{V}_{\mathrm{k}}^{2} \mathrm{~b}_{\mathrm{se}}+\mathrm{rV}_{\mathrm{k}}^{2}+\mathrm{V}_{\mathrm{k}} \mathrm{V}_{\mathrm{m}} \mathrm{b}_{\mathrm{se}} \cos \left(\delta_{\mathrm{k}}-\delta_{\mathrm{m}}\right)-\mathrm{rV}_{\mathrm{k}}^{2} \mathrm{~b}_{\mathrm{se}} \cos \gamma \\
& -\mathrm{t} . \mathrm{V}_{\mathrm{k}}^{2} \mathrm{~b}_{\mathrm{se}} \cos \sigma \\
& \mathrm{P}_{\mathrm{m}}^{\mathrm{OUPFC}}=-\mathrm{V}_{\mathrm{k}} \mathrm{V}_{\mathrm{m}} \mathrm{b}_{\mathrm{se}} \sin \left(\delta_{\mathrm{k}}-\delta_{\mathrm{m}}\right)-\mathrm{rV}_{\mathrm{k}} \mathrm{V}_{\mathrm{m} \cdot} \mathrm{b}_{\mathrm{se}} \sin \left(\delta_{\mathrm{k}}-\delta_{\mathrm{m}}+\gamma\right) \\
& -\mathrm{tV}_{\mathrm{k}} \mathrm{V}_{\mathrm{m}} \mathrm{b}_{\mathrm{se}} \sin \left(\delta_{\mathrm{k}}-\delta_{\mathrm{m}}+\sigma\right) \\
& \mathrm{Q}_{\mathrm{m}}^{\text {OUPFC }}=\mathrm{V}_{\mathrm{m}}^{2} \mathrm{~b}_{\mathrm{se}}-\mathrm{V}_{\mathrm{k}} \mathrm{V}_{\mathrm{m}} \mathrm{b}_{\mathrm{se}} \cos \left(\delta_{\mathrm{k}}-\delta_{\mathrm{m}}\right)-\mathrm{rV}_{\mathrm{k}} \mathrm{V}_{\mathrm{m} \cdot} \mathrm{b}_{\mathrm{se}} \cos \left(\delta_{\mathrm{k}}-\delta_{\mathrm{m}}+\gamma\right) \\
& +\mathrm{tV}_{\mathrm{k}} \mathrm{V}_{\mathrm{m}} \mathrm{b}_{\mathrm{se}} \cos \left(\delta_{\mathrm{k}}-\delta_{\mathrm{m}}+\sigma\right)
\end{aligned}
$$

\section{IV.DEVICE INCORPORATION PROCEDURE}

To analyze the effect of UPFC/OUPFC on a given power system, this device is incorporated in NewtonRaphson (NR) load flow solution. The developed current based model of UPFC/OUPFC is easily incorporated into the system by modifying Jacobian elements and power mismatch equations related to device connected buses [8].

The final steady state network equation in NR load flow in the presence of UPFC can be expressed as

$$
\left(\left[\begin{array}{c}
\Delta \mathrm{P} \\
\Delta \mathrm{Q}
\end{array}\right]+\left[\begin{array}{c}
\mathrm{P}^{\text {FACTS }} \\
\mathrm{Q}^{\text {FACTS }}
\end{array}\right]\right)=\left(\left[\begin{array}{cc}
\mathrm{H} & \mathrm{N} \\
\mathrm{J} & \mathrm{L}
\end{array}\right]+\left[\begin{array}{cc}
\mathrm{H}^{\text {FACTS }} & \mathrm{N}^{\text {FACTS }} \\
\mathrm{J}^{\text {FACTS }} & \mathrm{L}^{\text {FACTS }}
\end{array}\right]\right)\left[\begin{array}{c}
\Delta \delta \\
\frac{\Delta \mathrm{V}}{|\mathrm{V}|}
\end{array}\right]
$$

Where, ' $\Delta \mathrm{P}, \Delta \mathrm{Q}$ ' are the vector corresponds to real and reactive power mismatches, ' $\Delta \delta, \Delta \mathrm{V}$ ' are the vector of incremental changes in angles and voltages, ' $\mathrm{H}, \mathrm{N}, \mathrm{J}, \mathrm{L}$ ' are the partial derivatives of $\mathrm{P}$ and Q w.r.to $\delta$ and $\mathrm{V}$.

The corresponding Jacobian elements related to OUPFC connected buses are expressed as follows:

Jacobian elements related to CBM of OUPFC

The elements related to ' $\mathrm{H}$ ' matrix are obtained from equation (11)

$$
\begin{aligned}
& \frac{\partial \mathrm{P}_{\mathrm{k}} \text { OUPFC }}{\partial \delta_{\mathrm{k}}}=\left(-\mathrm{V}_{\mathrm{k}} \mathrm{V}_{\mathrm{m}} \mathrm{b}_{\mathrm{se}} \cos \left(\delta_{\mathrm{k}}-\delta_{\mathrm{m}}\right)-\mathrm{rV}_{\mathrm{k}} \mathrm{V}_{\mathrm{m} \cdot} \mathrm{b}_{\mathrm{se}}\left(\cos \left(\delta_{\mathrm{k}}-\delta_{\mathrm{m}}+\gamma\right)\right)\right. \text {. } \\
& -\mathrm{tV}_{\mathrm{k}} \mathrm{V}_{\mathrm{m}} \mathrm{b}_{\mathrm{se}}\left(\cos \left(\delta_{\mathrm{k}}-\delta_{\mathrm{m}}+\sigma\right)\right) \\
& \frac{\partial \mathrm{P}_{\mathrm{k}}^{\text {OUPFC }}}{\partial \delta_{\mathrm{m}}}=\left(\mathrm{V}_{\mathrm{k}} \mathrm{V}_{\mathrm{m}} \mathrm{b}_{\mathrm{se}} \cos \left(\delta_{\mathrm{k}}-\delta_{\mathrm{m}}\right)+\mathrm{rV}_{\mathrm{k}} \mathrm{V}_{\mathrm{m} \cdot} \mathrm{b}_{\mathrm{se}}\left(\cos \left(\delta_{\mathrm{k}}-\delta_{\mathrm{m}}+\gamma\right)\right)\right. \text {. } \\
& +\mathrm{tV}_{\mathrm{k}} \mathrm{V}_{\mathrm{m}} \mathrm{b}_{\mathrm{se}}\left(\cos \left(\delta_{\mathrm{k}}-\delta_{\mathrm{m}}+\sigma\right)\right) \\
& \frac{\partial \mathrm{Q}_{\mathrm{k}}{ }^{\text {OUPFC }}}{\partial \delta_{\mathrm{k}}}=-\mathrm{V}_{\mathrm{k}} \mathrm{V}_{\mathrm{m}} \mathrm{b}_{\mathrm{se}} \sin \left(\delta_{\mathrm{k}}-\delta_{\mathrm{m}}\right) \\
& \frac{\partial \mathrm{Q}_{\mathrm{k}}{ }^{\mathrm{OUPFC}}}{\partial \delta_{\mathrm{m}}}=-\mathrm{V}_{\mathrm{k}} \mathrm{V}_{\mathrm{m}} \mathrm{b}_{\mathrm{se}} \sin \left(\delta_{\mathrm{k}}-\delta_{\mathrm{m}}\right)
\end{aligned}
$$

The elements related to ' $N$ ' matrix are obtained from equation (12) 


$$
\begin{aligned}
& {\frac{\partial \mathrm{P}_{\mathrm{k}}}{\partial \mathrm{V}_{\mathrm{m}}}}^{\text {OUPFC }} \mathrm{V}_{\mathrm{m}}=\left(-\mathrm{V}_{\mathrm{k}} \mathrm{V}_{\mathrm{m}} \mathrm{b}_{\mathrm{se}} \sin \left(\delta_{\mathrm{k}}-\delta_{\mathrm{m}}\right)-\mathrm{rV}_{\mathrm{k}} \mathrm{V}_{\mathrm{m} .} \mathrm{b}_{\mathrm{se}}\left(\sin \left(\delta_{\mathrm{k}}-\delta_{\mathrm{m}}+\gamma\right)\right)\right. \\
& -\mathrm{tV}_{\mathrm{k}} \mathrm{V}_{\mathrm{m}} \mathrm{b}_{\mathrm{se}}\left(\sin \left(\delta_{\mathrm{k}}-\delta_{\mathrm{m}}+\sigma\right)\right) \\
& \frac{\partial \mathrm{Q}_{\mathrm{k}} \text { OUPFC }}{\partial \mathrm{V}_{\mathrm{k}}} \mathrm{V}_{\mathrm{k}}=-2 \mathrm{~V}_{\mathrm{k}}^{2} \mathrm{~b}_{\mathrm{se}}+2 \mathrm{rV}_{\mathrm{k}}^{2}+\mathrm{V}_{\mathrm{k}} \mathrm{V}_{\mathrm{m}} \mathrm{b}_{\mathrm{se}} \cos \left(\delta_{\mathrm{k}}-\delta_{\mathrm{m}}\right) \\
& -2 \mathrm{rV}_{\mathrm{k}}^{2} \mathrm{~b}_{\mathrm{se}} \cos \gamma-2 \mathrm{tV}_{\mathrm{k}}{ }^{2} \mathrm{~b}_{\mathrm{se}} \cos \sigma \\
& \frac{\partial \mathrm{Q}_{\mathrm{k}}{ }^{\text {OUPFC }}}{\partial \mathrm{V}_{\mathrm{m}}} \mathrm{V}_{\mathrm{m}}=\mathrm{V}_{\mathrm{k}} \mathrm{V}_{\mathrm{m}} \mathrm{b}_{\mathrm{se}} \cos \left(\delta_{\mathrm{k}}-\delta_{\mathrm{m}}\right)
\end{aligned}
$$

The elements related to ' $\mathrm{J}$ ' matrix are obtained from (13)

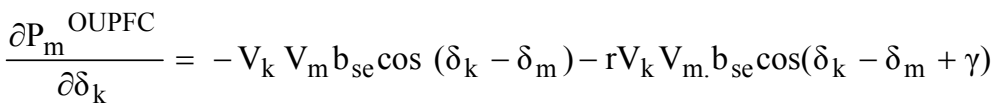

$$
\begin{aligned}
& -\mathrm{tV}_{\mathrm{k}} \mathrm{V}_{\mathrm{m}} \mathrm{b}_{\mathrm{se}} \cos \left(\delta_{\mathrm{k}}-\delta_{\mathrm{m}}+\sigma\right) \\
& {\frac{\partial \mathrm{P}_{\mathrm{m}}}{\partial \delta_{\mathrm{m}}}}^{\text {OUPFC }}=\mathrm{V}_{\mathrm{k}} \mathrm{V}_{\mathrm{m}} \mathrm{b}_{\mathrm{se}} \cos \left(\delta_{\mathrm{k}}-\delta_{\mathrm{m}}\right)+\mathrm{rV}_{\mathrm{k}} \mathrm{V}_{\mathrm{m} \cdot} \mathrm{b}_{\mathrm{se}} \cos \left(\delta_{\mathrm{k}}-\delta_{\mathrm{m}}+\gamma\right) \\
& \left.+\mathrm{tV}_{\mathrm{k}} \mathrm{V}_{\mathrm{m}} \mathrm{b}_{\mathrm{se}} \cos \left(\delta_{\mathrm{k}}-\delta_{\mathrm{m}}+\sigma\right)\right) \\
& \frac{\partial \mathrm{Q}_{\mathrm{m}}{ }^{\text {OUPFC }}}{\partial \delta_{\mathrm{k}}}=-\mathrm{V}_{\mathrm{k}} \mathrm{V}_{\mathrm{m}} \mathrm{b}_{\mathrm{se}} \sin \left(\delta_{\mathrm{k}}-\delta_{\mathrm{m}}\right)+\mathrm{rV}_{\mathrm{k}} \mathrm{V}_{\mathrm{m} .} \mathrm{b}_{\mathrm{se}} \sin \left(\delta_{\mathrm{k}}-\delta_{\mathrm{m}}+\gamma\right) \\
& -\mathrm{tV}_{\mathrm{k}} \mathrm{V}_{\mathrm{m}} \mathrm{b}_{\mathrm{se}} \sin \left(\delta_{\mathrm{k}}-\delta_{\mathrm{m}}+\sigma\right) \\
& {\frac{\partial \mathrm{Q}_{\mathrm{m}}}{\partial \delta_{\mathrm{m}}}}^{\text {OUPFC }}=\mathrm{V}_{\mathrm{k}} \mathrm{V}_{\mathrm{m}} \mathrm{b}_{\mathrm{se}} \sin \left(\delta_{\mathrm{k}}-\delta_{\mathrm{m}}\right)-\mathrm{rV}_{\mathrm{k}} \mathrm{V}_{\mathrm{m} .} \mathrm{b}_{\mathrm{se}} \sin \left(\delta_{\mathrm{k}}-\delta_{\mathrm{m}}+\gamma\right) \\
& +\mathrm{tV}_{\mathrm{k}} \mathrm{V}_{\mathrm{m}} \mathrm{b}_{\mathrm{se}} \sin \left(\delta_{\mathrm{k}}-\delta_{\mathrm{m}}+\sigma\right)
\end{aligned}
$$

The elements related to ' $\mathrm{L}$ ' matrix are obtained from (14)

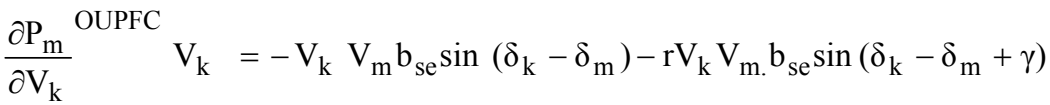

$$
\begin{aligned}
& -\mathrm{tV}_{\mathrm{k}} \backslash \mathrm{V}_{\mathrm{m}} \mathrm{b}_{\mathrm{se}} \sin \left(\delta_{\mathrm{k}}-\delta_{\mathrm{m}}+\sigma\right)
\end{aligned}
$$

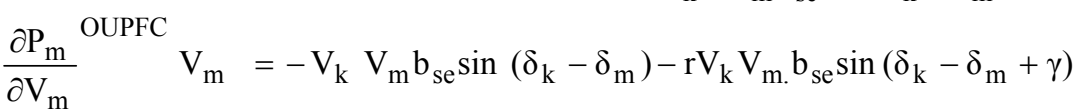

$$
\begin{aligned}
& -\mathrm{tV}_{\mathrm{k}} \mathrm{V}_{\mathrm{m}} \mathrm{b}_{\mathrm{se}} \sin \left(\delta_{\mathrm{k}}-\delta_{\mathrm{m}}+\sigma\right)
\end{aligned}
$$

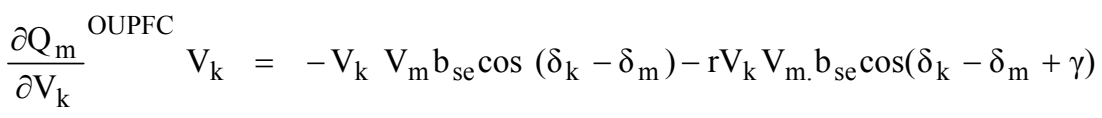

$$
\begin{aligned}
& +\mathrm{tV}_{\mathrm{k}} \mathrm{V}_{\mathrm{m}} \mathrm{b}_{\mathrm{se}} \cos \left(\delta_{\mathrm{k}}-\delta_{\mathrm{m}}+\sigma\right.
\end{aligned}
$$

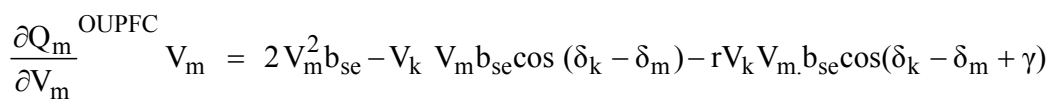

$$
\begin{aligned}
& +\mathrm{tV}_{\mathrm{k}} \mathrm{V}_{\mathrm{m}} \mathrm{b}_{\mathrm{se}} \cos \left(\delta_{\mathrm{k}}-\delta_{\mathrm{m}}+\sigma\right)
\end{aligned}
$$

\section{POWER FLOW SOLUTION IN THE PRESENCE OF OUPFC}

The overall computational procedure of Newton-Raphson power flow method with OUPFC is described in the following steps.

$>$ Read bus data, line data and OUPFC data.

$>$ Assume flat voltage profile and set iteration count $\mathrm{k}=0$.

$>$ Compute active and reactive power mismatch from the scheduled and calculated powers.

$>$ Determine Jacobian matrix using power flow equations.

$>$ Modify power mismatch and Jacobian elements related to OUPFC connected buses to incorporate OUPFC.

$>$ Solve the NR method to find the voltage magnitudes and angles correction vector. 
$>$ Update the solution using correction vector.

$>$ Increase the iteration count, $\mathrm{k}=\mathrm{k}+1$.

$>$ Stop the process, if tum mismatch is less than given tolerance and print the output. Otherwise, go to step 3.

\section{VI.RESULTS AND ANALYSIS}

In this section, to show the effectiveness of OUPFC over the existing PST and UPFC, the analysis is performed for the following two cases.

Case-1: Analysing the effect of OUPFC on system parameters by varying device control parameters.

Case-2: Comparing the effectiveness of OUPFC over the existing PST and UPFC with respective numerical results.

For this analysis, the device control parameter variation for the considered devices is as follows:

1. For PST: The transfer ratio $\left(\mathrm{k}=\sqrt{\left(\mathrm{a}^{2}+\mathrm{b}^{2}\right)}\right)$ of PST voltage injection is varied from 0 p.u to 0.1 p.u. and phase angle $\left(\sigma=\tan ^{-1}\left(\frac{\mathrm{b}}{\mathrm{a}}\right)\right)$ is varied from $-45 \operatorname{deg}$ to $45 \operatorname{deg}$ [49].

2. For UPFC: The radius of the operating region (r) is varied from 0 p.u. to 0.1 p.u and respective phase angle $(\gamma)$ is varied from $-180 \mathrm{deg}$ to $180 \mathrm{deg}$.

3. For OUPFC: The control parameters variation for both PST $(\mathrm{k}, \sigma)$ and $\operatorname{UPFC}(\mathrm{r}, \gamma)$ are considered as this device is a combination of PST and UPFC.

\section{A. Example-1}

In this example, IEEE-5 bus system popularly known as Hale network with two generators, seven transmission lines is considered [9]. The total load on this system is $165 \mathrm{MW}$. To show effect of these devices, predominantly transmission line connected between buses 4 and 5 (Line-7) with shunt converter placed at bus- 4 is considered to install these devices. The reactance of the series converter transformer is considered to be 0.1 p.u.

For Case-1, the OUPFC control parameters $\mathrm{k}$ and $\sigma$ are fixed at $0.08 \mathrm{p} . \mathrm{u}$ and $18.028 \mathrm{deg}$ and the parameters $\mathrm{r}$ is varied from 0 p.u. to 0.1 p.u and $\gamma$ is varied from $-180 \mathrm{deg}$ to $180 \mathrm{deg}$. The variation of bus voltage magnitudes with OUPFC is shown in Fig.5, variation of power flow, power losses and number of iterations is shown in Figs.6 and 7. From these figures, it is identified that, value of the system parameters (voltage magnitude, power flow, losses) is increasing as the device control parameters value is varied from minimum setting ( $\mathrm{r}=0 \mathrm{p} . \mathrm{u})$ to maximum setting $(\mathrm{r}=0.1 \mathrm{p} . \mathrm{u})$.
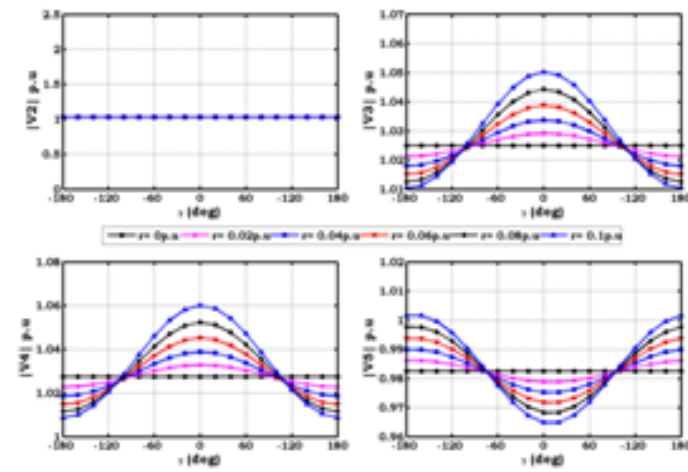

Fig.5 Variation of bus voltage magnitude with OUPFC for HALE network

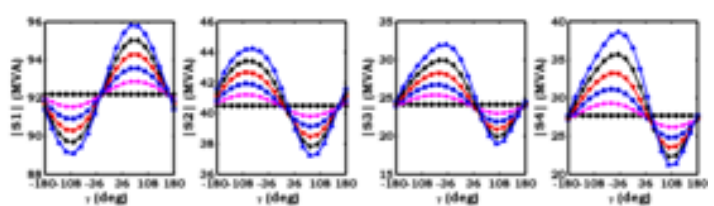

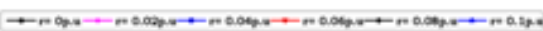

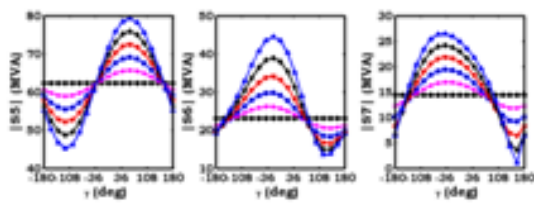

Fig.6 Variation of line power flow with OUPFC for HALE network 


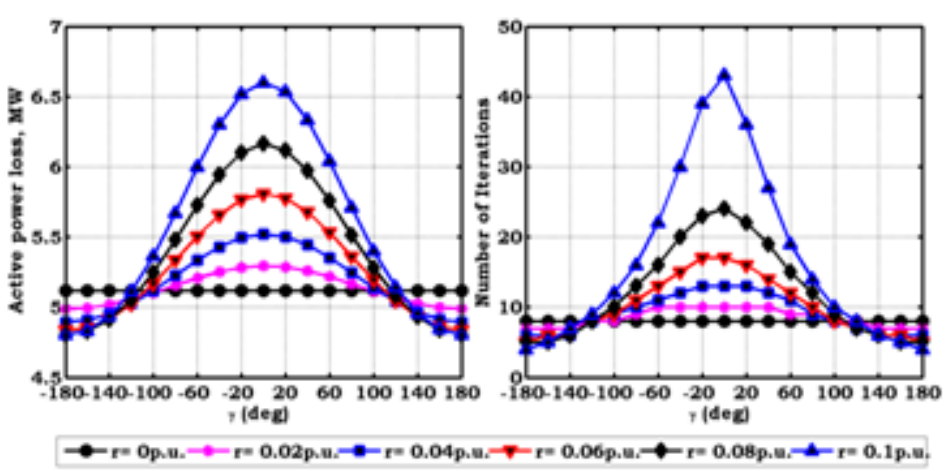

Fig.7 Variation of power losses and iterations with OUPFC for HALE network

To show more clearly the effect of OUPFC on system parameters, the consolidated variation of system parameters for the variation of device control parameters is shown in Figs. 8 and 9. Fig.8 clearly shows that, voltage magnitude at bus- 4 has major variation as the device shunt converter is connected at this bus. Similarly from Fig.9, the power flow in the device connected line (7th line) and nearby line (5th line) has got major variations. It is also observed that, the power flow in line- 5 can be varied up to its maximum limit.

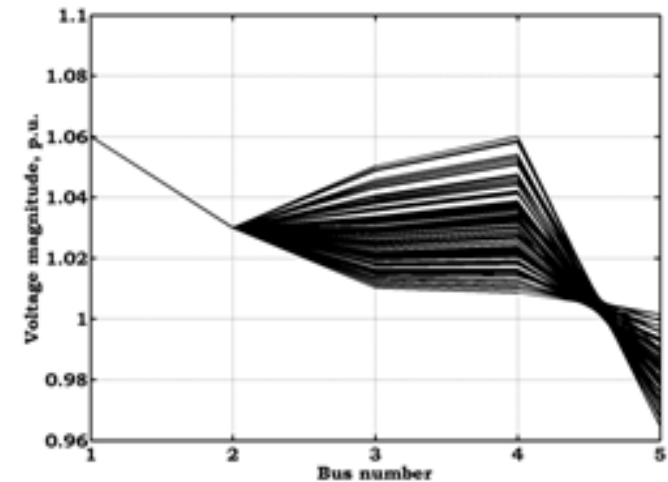

Fig.8 Consolidated variation of bus voltage magnitude by varying OUPFC control parameters for HALE network

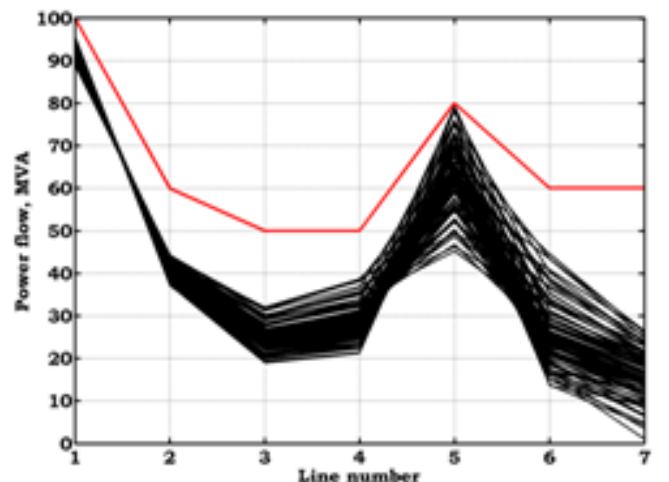

Fig.9 Consolidated variation of line power flow by varying OUPFC control parameters for HALE network

In Case-2, to show the effectiveness of OUPFC over PST and UPFC, variation of voltage magnitude difference (Vmax-Vmin) at each bus is shown in Fig.10, power flow difference (Pmax-Pmin) in each line is shown in Fig.11 and variation of power losses is shown in Fig.12.

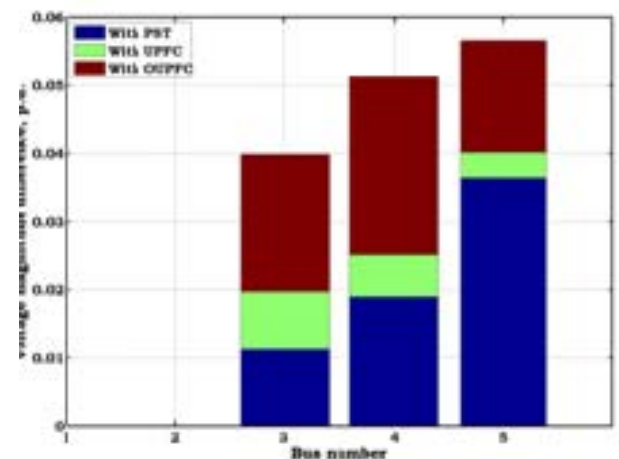

Fig.10 Variation of voltage magnitude difference with PST UPFC and OUPFC for HALE network

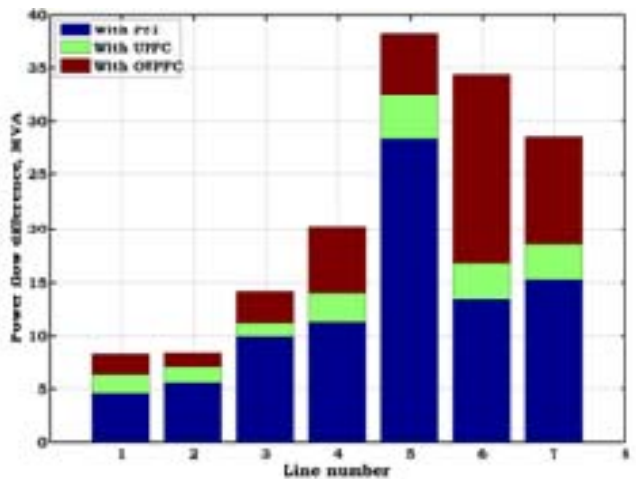

Fig.11 Variation of power flow difference with PST, UPFC and OUPFC for HALE network 


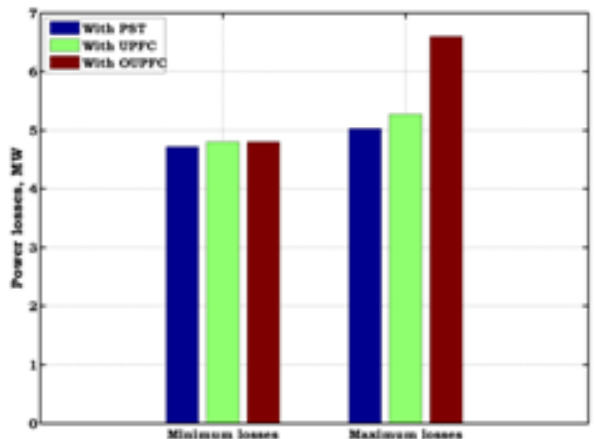

Fig.12 Variation of power losses with PST, UPFC and OUPFC for HALE network

The numerical results of the losses with respective PST, UPFC and OUPFC control parameters are tabulated in Table.1. From this table, it is observed that, due to simplified mathematical equations solved with $\mathrm{CB}$ of OUPFC, the number of iterations taken to solve load flow is decreased.

TABLE.I Numerical results of the losses and respective device control parameters for HALE network

\begin{tabular}{|c|c|c|c|c|c|}
\hline \multirow{4}{*}{ Existing } & $\begin{array}{l}\text { FACTs } \\
\text { Device }\end{array}$ & $\begin{array}{l}\text { TPL Minimum(MW) } \\
\text { (control parameters) }\end{array}$ & $\begin{array}{l}\text { Number of } \\
\text { Iterations }\end{array}$ & $\begin{array}{l}\text { TPL Maximum(MW) } \\
\text { (control parameters) }\end{array}$ & $\begin{array}{c}\text { Number } \\
\text { of } \\
\text { Iterations }\end{array}$ \\
\hline & PST & $\begin{array}{c}4.723836 \\
(\mathrm{k}=0.01 \text { p.u, } \sigma=-24.54 \mathrm{deg})\end{array}$ & 04 & $\begin{array}{c}5.029837 \\
(\mathrm{k}=0.1 \text { p.u, } \sigma=43.76 \mathrm{deg})\end{array}$ & 18 \\
\hline & UPFC & $\begin{array}{c}4.803002368 \\
(\mathrm{r}=0.02 \text { p.u, } \gamma=-20 \mathrm{deg})\end{array}$ & 04 & $\begin{array}{c}5.2735 \\
(\mathrm{r}=0.1 \mathrm{p} . \mathrm{u}, \gamma=140 \mathrm{deg})\end{array}$ & 27 \\
\hline & PIM of OUPFC & $\begin{array}{c}4.7728371 \\
(\mathrm{r}=0.089 \text { p.u, } \gamma=153 \mathrm{deg} \\
\mathrm{k}=0.08 \text { p.u, } \sigma=-18.28 \mathrm{deg})\end{array}$ & 11 & $\begin{array}{c}6.57487312 \\
(\mathrm{r}=0.042 \text { p.u, } \gamma=88 \mathrm{deg}, \\
\mathrm{k}=0.08 \text { p.u, } \sigma=-18.28 \mathrm{deg})\end{array}$ & 59 \\
\hline Proposed & CB of OUPFC & $\begin{array}{c}4.803151214 \\
(\mathrm{r}=0.1 \text { p.u, } \gamma=180 \mathrm{deg} \\
\mathrm{k}=0.08 \text { p.u, } \sigma=-18.28 \mathrm{deg})\end{array}$ & 05 & $\begin{array}{c}6.601383 \\
(\mathrm{r}=0.1 \text { p.u, } \gamma=0 \mathrm{deg}, \\
\mathrm{k}=0.08 \text { p.u, } \sigma=-18.28 \mathrm{deg})\end{array}$ & 42 \\
\hline
\end{tabular}

\section{B. Example-2}

In this example, IEEE-14 bus system with five generators connected at buses 1, 2, 3, 6 and 8, twenty transmission lines, three tap changing transformers (lines 8, 9 and 10 connected between buses 4-7, 4-9 and 5-6) and one shunt compensator (connected at bus-9) is considered. The total load on this system is 259 MW. To show effect of these devices, based on [10], predominantly transmission line connected between buses 7 and 9 (Line-15) with shunt converter placed at bus-7 is considered to install these devices. The reactance of the series converter transformer is considered to be 0.2 p.u.

For Case-1, to show the effect of OUPFC on system parameters, the consolidated variation of system parameters for the variation of device control parameters is shown in Figs. 13-15. Fig.13 clearly shows that, voltage magnitude at bus-9 has major variation as the device is connected at this bus. Similarly from Fig.14, the power flow in the device connected line (15th line) and nearby lines (14th and 16th lines) has got major variations. It is also observed that, the power flow in line-15 can be varied from lower limit to upper limit. From Fig.15, it is observed that, minimum and maximum power losses are obtained when device is at maximum operating limit. It is also observed that, due to increased mathematical computations with OUPFC, the number of iterations taken to solve load flow is also increased.

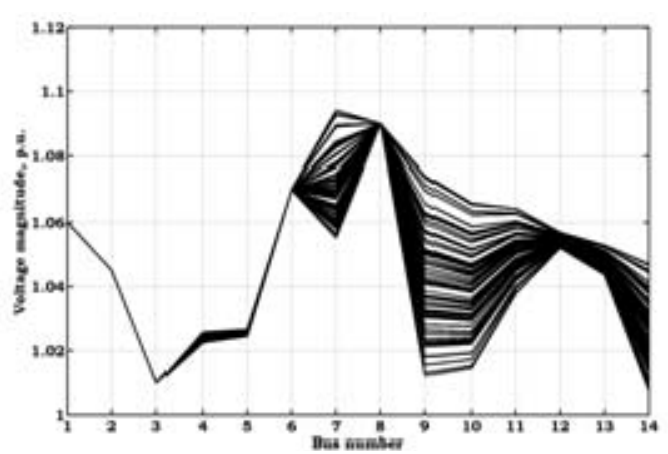

Fig.13 Variation of bus voltage magnitude by varying OUPFC control parameters for IEEE-14 bus system

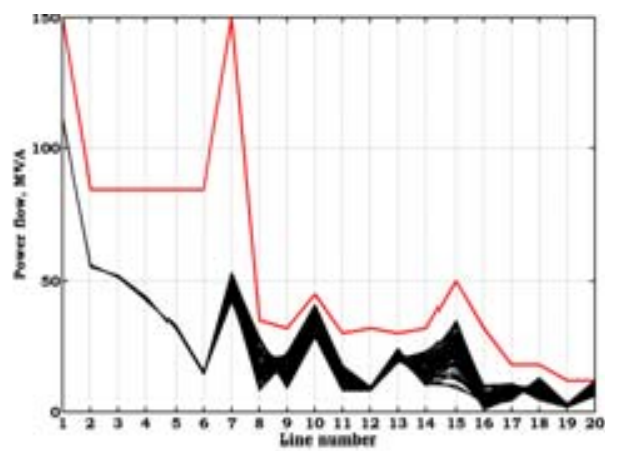

Fig.14 Variation of line power flow by varying OUPFC control parameters for IEEE-14 bus system 

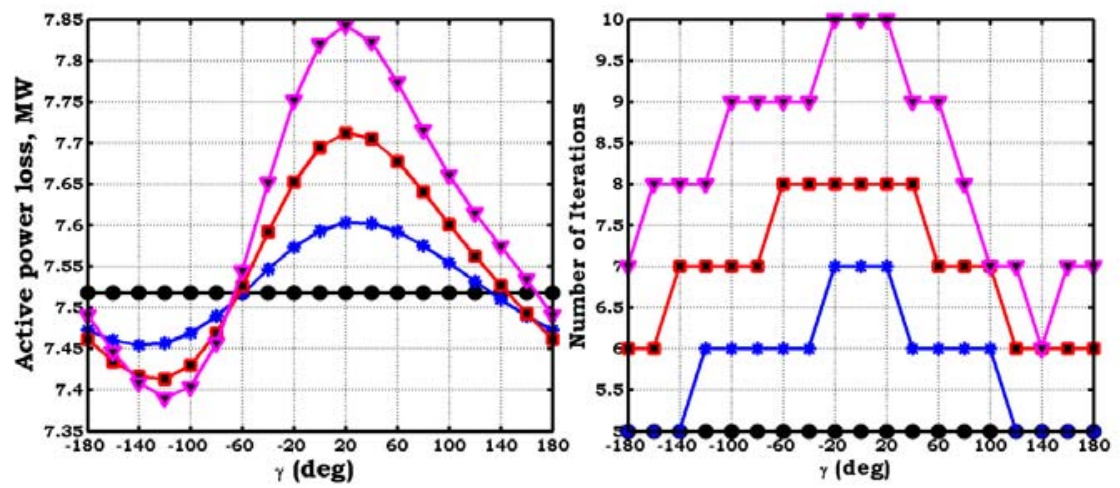

$\rightarrow-x=0$ p.u. $\rightarrow-x=0.03 p . u . \rightarrow-x=0.06 p . u . \rightarrow r=0.09 p . u$.

Fig.15 Variation of power losses and iterations with OUPFC for IEEE-14 bus system

In Case-2, to show the effectiveness of OUPFC over PST and UPFC, variation of voltage magnitude difference (Vmax-Vmin) at each bus is shown in Fig.16, power flow difference (Pmax-Pmin) in each line is shown in Fig. 17 and variation of power losses is shown in Fig.18.

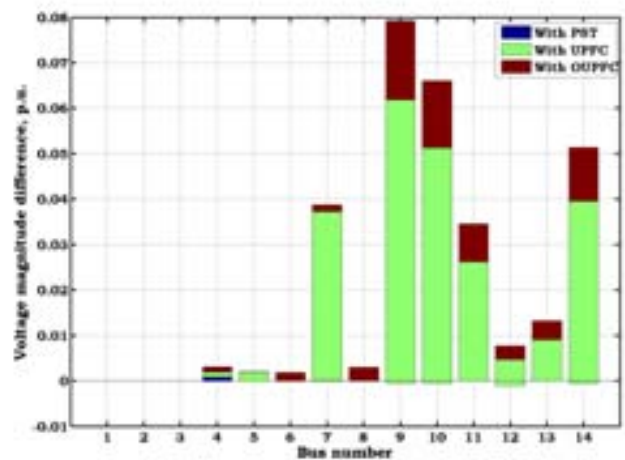

Fig.16 Variation of voltage magnitude difference with PST UPFC and OUPFC for IEEE-14 bus system

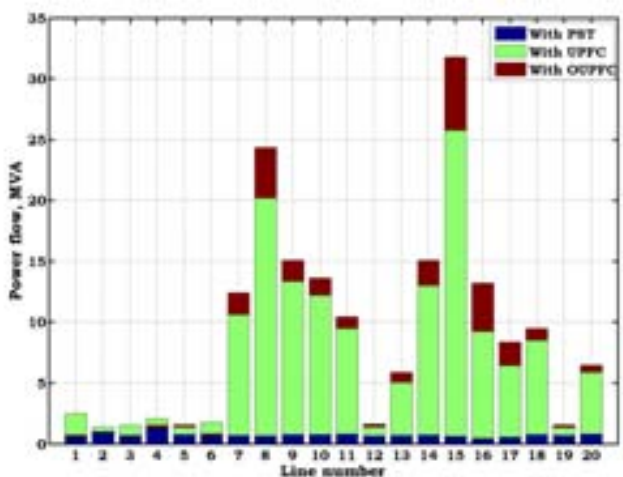

Fig.17 Variation of power flow difference with PST, UPFC and OUPFC for IEEE-14 bus system

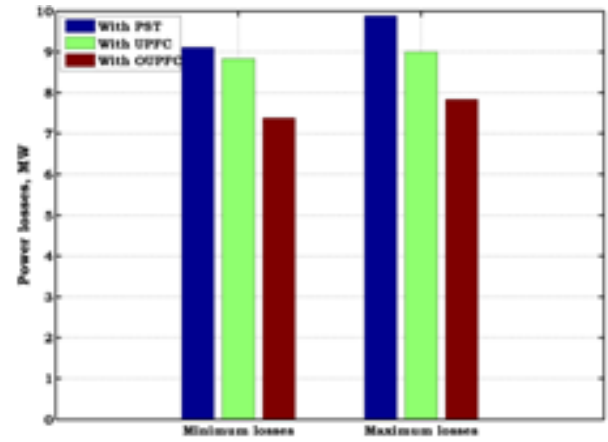

Fig.18 Variation of power losses with PST, UPFC and OUPFC for IEEE-14 bus system

The numerical results of the losses with respective PST, UPFC and OUPFC control parameters are tabulated in Table.2. From this table, it is observed that, due to simplified mathematical equations solved with $\mathrm{CB}$ of OUPFC, the number of iterations taken to solve load flow is decreased. 
TABLE.II Numerical results of the losses and respective device control parameters for IEEE-14 bus system network

\begin{tabular}{|c|c|c|c|c|c|}
\hline & $\begin{array}{l}\text { FACTs } \\
\text { Device }\end{array}$ & $\begin{array}{l}\text { TPL Minimum(MW) } \\
\text { (control parameters) }\end{array}$ & $\begin{array}{l}\text { Number of } \\
\text { Iterations }\end{array}$ & $\begin{array}{l}\text { TPL Maximum(MW) } \\
\text { (control parameters) }\end{array}$ & $\begin{array}{l}\text { Number of } \\
\text { Iterations }\end{array}$ \\
\hline \multirow{3}{*}{$\begin{array}{l}\text { Existing } \\
\text { model }\end{array}$} & PST & $\begin{array}{c}9.120229 \\
(\mathrm{k}=0.01 \text { p.u, } \sigma=-24.54 \mathrm{deg})\end{array}$ & 03 & $\begin{array}{c}9.8827736 \\
(\mathrm{k}=0.1 \mathrm{p} . \mathrm{u}, \sigma=43.76 \mathrm{deg})\end{array}$ & 12 \\
\hline & UPFC & $\begin{array}{c}8.837465 \\
\text { (r=0.02 p.u, } \gamma=-20 \mathrm{deg})\end{array}$ & 07 & $\begin{array}{c}9.0059176 \\
(\mathrm{r}=0.1 \text { p.u, } \gamma=140 \mathrm{deg})\end{array}$ & 18 \\
\hline & PIM of OUPFC & $\begin{array}{c}8.293881 \\
(\mathrm{r}=0.098 \text { p.u, } \gamma=63 \mathrm{deg} \\
\mathrm{k}=0.08 \text { p.u, } \sigma=-18.28 \mathrm{deg})\end{array}$ & 14 & $\begin{array}{c}8.958473 \\
(\mathrm{r}=0.02 \text { p.u, } \gamma=-13 \mathrm{deg} \\
\mathrm{k}=0.08 \text { p.u, } \sigma=-18.28 \mathrm{deg})\end{array}$ & 23 \\
\hline $\begin{array}{l}\text { Proposed } \\
\text { model }\end{array}$ & CB of OUPFC & $\begin{array}{c}7.390248 \\
(\mathrm{r}=0.09 \text { p.u, } \gamma=-120 \mathrm{deg} \\
\mathrm{k}=0.08 \text { p.u, } \sigma=-18.28 \mathrm{deg})\end{array}$ & 08 & $\begin{array}{c}7.842355 \\
(\mathrm{r}=0.1 \text { p.u, } \gamma=0 \mathrm{deg}, \\
\mathrm{k}=0.08 \text { p.u, } \sigma=-18.28 \mathrm{deg})\end{array}$ & 15 \\
\hline
\end{tabular}

\section{Example-3}

In this example, IEEE-30 bus system with six generators connected at buses 1, 2, 5, 8, 11 and 13, forty one transmission lines, four tap changing transformers (lines 11, 12, 15 and 36 connected between buses 6-9, 6-10, 4-12 and 28-27) and two shunt compensators (connected at buses 10 and 24) is considered. The total load on this system is $283.4 \mathrm{MW}$. To show effect of these devices, based on [11], predominantly transmission line connected between buses 6 and 7 (Line-9) with shunt converter placed at bus- 6 is considered to install these devices. The reactance of the series converter transformer is considered to be 0.2 p.u.

For Case-1, to show the effect of OUPFC on system parameters, the consolidated variation of system parameters for the variation of device control parameters is shown in Figs. 19-21. Fig.19 clearly shows that, voltage magnitude at bus-7 has major variation as the device is connected at this bus. Similarly from Fig.20, the power flow in the device connected line (9th line) and nearby lines (5th, 6th, 7th, 8th, and 10th lines) has got major variations. It is also observed that, the power flow in line- 9 can be varied from lower limit to upper limit. From Fig.21, it is observed that, minimum and maximum power losses are obtained when device is at maximum operating limit. It is also observed that, due to increased mathematical computations with OUPFC, the number of iterations taken to solve load flow is also increased.

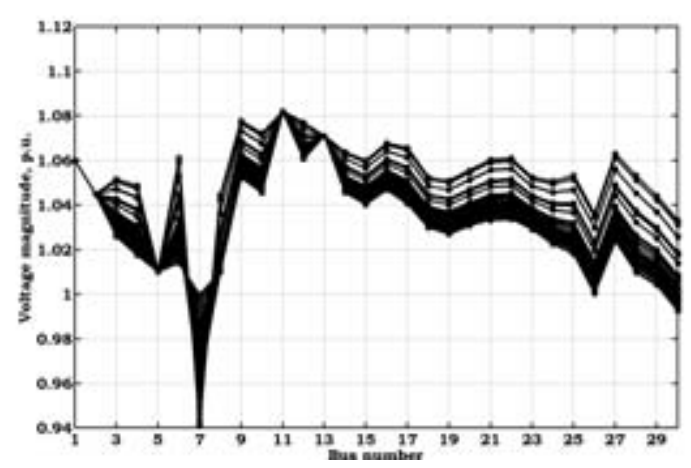

Fig.19 Variation of bus voltage magnitude by varying OUPFC control parameters for IEEE-30 bus system

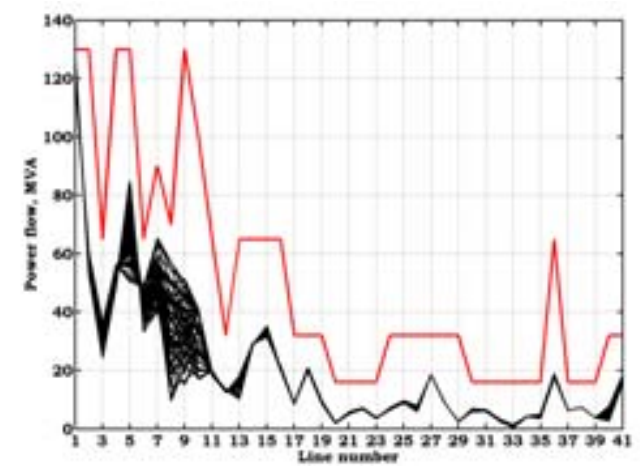

Fig.20 Variation of line power flow by varying OUPFC control parameters for IEEE-30 bus system

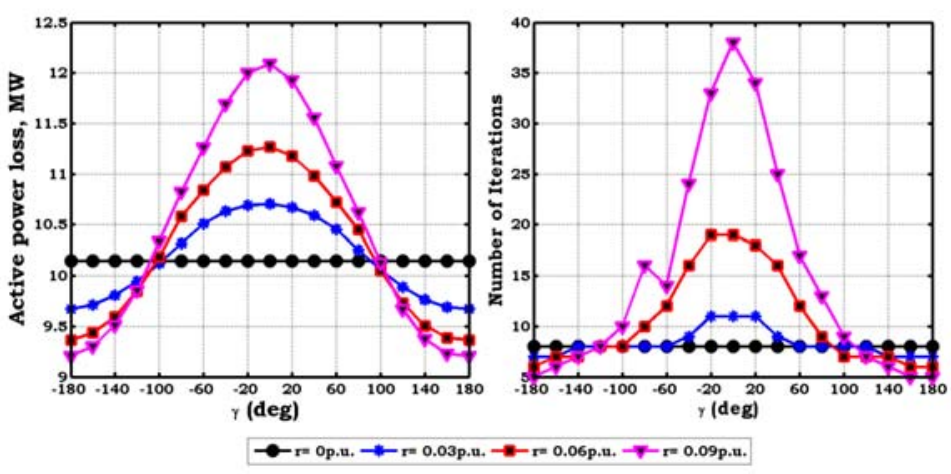

Fig.21 Variation of power losses and iterations with OUPFC for IEEE-30 bus system 
In Case-2, to show the effectiveness of OUPFC over PST and UPFC, variation of voltage magnitude difference (Vmax-Vmin) at each bus is shown in Fig.22, power flow difference (Pmax-Pmin) in each line is shown in Fig.23 and variation of power losses is shown in Fig.24.

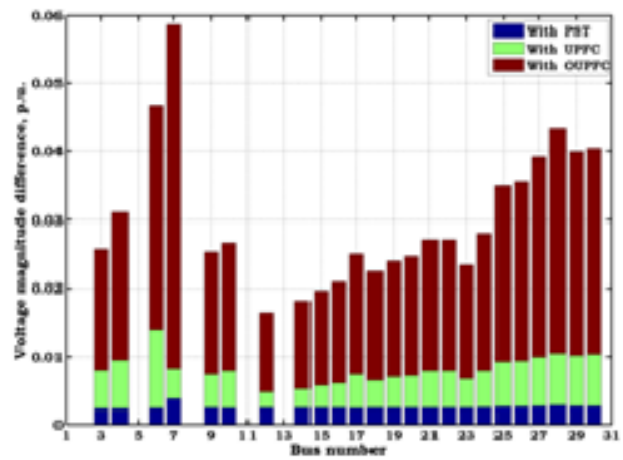

Fig.22 Variation of voltage magnitude difference with PST UPFC and OUPFC for IEEE-30 bus system

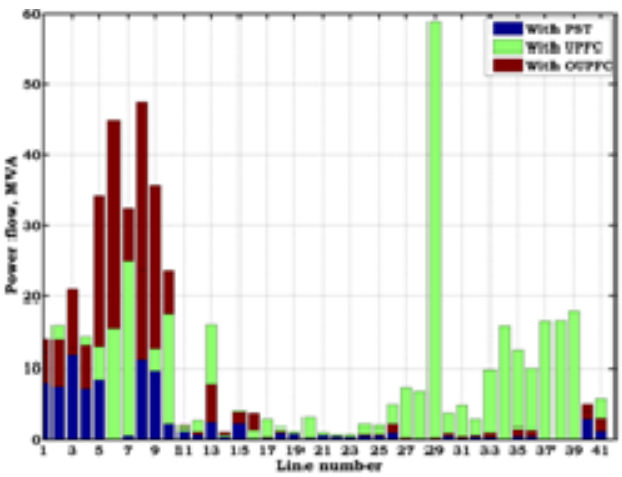

Fig.23 Variation of power flow difference with PST, UPFC and OUPFC for IEEE-30 bus system

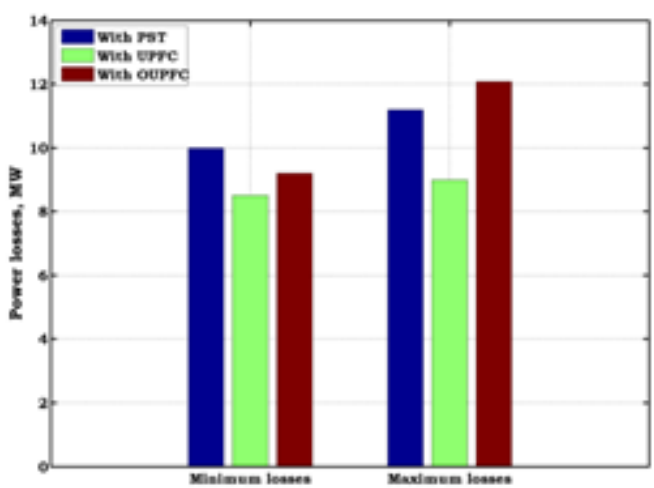

Fig.24 Variation of power losses with PST, UPFC and OUPFC for IEEE-30 bus system

he numerical results of the losses with respective PST, UPFC and OUPFC control parameters are tabulated in Table.3. From this table, it is observed that, due to simplified mathematical equations solved with $\mathrm{CB}$ of OUPFC, the number of iterations taken to solve load flow is decreased.

TABLE.III Numerical results of the losses and respective device control parameters for IEEE-30 bus system

\begin{tabular}{|c|c|c|c|c|c|}
\hline & $\begin{array}{c}\text { FACTs } \\
\text { Device }\end{array}$ & $\begin{array}{c}\text { TPL Minimum } \\
\text { (MW) (control } \\
\text { parameters) } \\
\end{array}$ & $\begin{array}{l}\text { Number of } \\
\text { Iterations }\end{array}$ & $\begin{array}{c}\text { TPL Maximum } \\
\text { (MW) (control } \\
\text { parameters) }\end{array}$ & $\begin{array}{l}\text { Number of } \\
\text { Iterations }\end{array}$ \\
\hline \multirow{3}{*}{ Existing model } & PST & $\begin{array}{c}9.9928 \\
(\mathrm{k}=0.045 \text { p.u, } \\
\sigma=-25.54 \mathrm{deg})\end{array}$ & 06 & $\begin{array}{c}11.2039 \\
(\mathrm{k}=0.05 \mathrm{p} . \mathrm{u} \\
\sigma=119.29 \mathrm{deg})\end{array}$ & 10 \\
\hline & UPFC & $\begin{array}{c}8.5148 \\
(\mathrm{r}=0.03 \mathrm{p} . \mathrm{u} \\
\gamma=120 \mathrm{deg})\end{array}$ & 11 & $\begin{array}{l}9.0059176 \\
\text { (r=0.09 p.u, } \\
\gamma=340 \mathrm{deg})\end{array}$ & 30 \\
\hline & PIM of OUPFC & $\begin{array}{c}9.9283 \\
(\mathrm{r}=0.07 \text { p.u, } \\
\gamma=22 \mathrm{deg}, \\
\mathrm{k}=0.08 \mathrm{p} . \mathrm{u}, \\
\sigma=-18.28 \mathrm{deg})\end{array}$ & 14 & $\begin{array}{c}13.2039 \\
(\mathrm{r}=0.09 \mathrm{p} . \mathrm{u}, \\
\gamma=-28.34 \mathrm{deg} \\
\mathrm{k}=0.08 \mathrm{p.u} \\
\sigma=-18.28 \mathrm{deg})\end{array}$ & 42 \\
\hline $\begin{array}{c}\text { Proposed } \\
\text { model }\end{array}$ & $\mathrm{CB}$ of OUPFC & $\begin{array}{c}9.2082 \\
(\mathrm{r}=0.09 \mathrm{p} . \mathrm{u}, \\
\gamma=-180 \mathrm{deg} \\
\mathrm{k}=0.08 \mathrm{p} . \mathrm{u}, \\
\sigma=-18.28 \mathrm{deg})\end{array}$ & 08 & $\begin{array}{c}12.0901 \\
(\mathrm{r}=0.09 \mathrm{p} . \mathrm{u} \\
\gamma=0 \mathrm{deg} \\
\mathrm{k}=0.08 \mathrm{p.u} \\
\sigma=-18.28 \mathrm{deg})\end{array}$ & 37 \\
\hline
\end{tabular}




\section{CONCLUSION}

In this paper, current based model of OUPFC with supporting mathematical derivation has been presented with its incorporation procedure to solve load flow problem. The effectiveness of OUPFC on system parameters such as bus voltages, power flow in transmission lines and total power losses have been analyzed and compared with the existing PST and OUPFC. From the analysis, it has been identified that, due to controlling of multiple parameters with OUPFC, the voltage magnitude at the device shunt converter connected bus and the power flow in the device series converter connected line have been enhanced to minimize the total power losses. The numerical results along with supporting graphical results have been presented for the considered IEEE-5 bus, IEEE-14 bus and IEEE-30 bus test systems.

\section{REFERENCES}

[1] Rajive Tiwari, K. R. Niazi, Vikas Gupta., "Variable series impedance model of a unified power flow controller for load flow analysis", Electric Power Components and Systems, 2012, Vol.40, pp.74-92.

[2] B. Venkateswara Rao, G.V. Nagesh Kumar, "Optimal power flow by BAT search algorithm for generation reallocation with unified power flow controller", Electrical Power and Energy Systems, 2015, Vol.68, pp.81-88.

[3] Anton Vinkovic, Marko Suhadolc, Rafael Mihalic, "Current-based models of FACTS devices for three-phase load-flow calculations using the Newton-Raphson method", Electrical Power and Energy Systems, 2013, Vol.45, pp.117-128.

[4] A.Khorsandi, S.H. Hosseinian, A. Ghazanfari, "Modified artificial bee colony algorithm based on fuzzy multi-objective technique for optimal power flow problem," Electric power systems research, Vol.95, 2013, PP. 206-213.

[5] Adriane B S Serapiao., "Cuckoo search for solving economic dispatch load problem", Intelligent control and automation, Scientific Research, 2013, Vol.4, pp.391-396.

[6] A. Lashkar Ara, A. Kazemi, S.A. Nabavi Naiki., "Modelling of Optimal Unified Power Flow Controller (OUPFC) for optimal steadystate performance of power systems", Energy Conversion and Management, 2011, Vol.52, pp.1325-1333.

[7] A. Lashkar Ara, J.Aghaei, M. Alaleh, H.Barati., "Contingency based optimal placement of Optimal Unified Power Flow Controller (OUPFC) in electrical energy transmission systems", Scientia Iranica D, 2013, Vol.20, No.3, pp.778-785.

[8] M. Tumay, A.M.Vural, K.L.Lo., "The effect of unified power flow controller location in power systems", Electrical Power and Energy Systems, 2004, Vol.26, pp.561-569.

[9] G. W. Stagg, A. H. El-Abiad, “Computer Methods in Power System Analysis”, ser. Electronic Systems. McGraw-Hill, 1968.

[10] http://www.ee.washington.edu/research/pstca/pf14/pg_tca14bus.htm

[11] http://www.ee.washington.edu/research/pstca/pf30/pg_tca30bus.htm

\section{AUTHOR PROFILE}

D.Srilatha received her B.Tech. in Electrical Engineering from JNT University, Hyderabad \& MTech in Power system High voltage engineering from JNT University, Kakinada. She is currently pursuing Ph.D. at JNT University, Kakinada. She has been working as Associate Professor in Prakasam engineering college kandukur for the last 12 years. Her research interest areas are FACTS controllers, power system security, and Power quality, special electrical machines.

Dr. S. Sivanagaraju is Professor in the department of Electrical and Electronics Engineering, University College of Engineering Kakinada, Jawaharlal Nehru Technological University Kakinada, Kakinada, AP, India. He completed his master's degree from Indian Institute of Technology, Khargpur, India, in electrical power systems. He completed his doctoral program in Jawaharlal Nehru Technological University Hyderabad, Andhra Pradesh, India. His interests include FACTS Controllers, Electrical Distribution System Automation, Optimization Techniques, Voltage Stability, Power System Analysis, and Power System Operation and Control. 